\title{
Gilles Banderier, Une lettre inédite d'Elie Vinet
}

\section{Filippo Fonio}

\section{(2) OpenEdition}

\section{Journals}

\section{Edizione digitale}

URL: http://journals.openedition.org/studifrancesi/35902

DOI: 10.4000/studifrancesi.35902

ISSN: 2427-5856

\section{Editore}

Rosenberg \& Sellier

\section{Edizione cartacea}

Data di pubblicazione: 1 juillet 2005

Paginazione: 148

ISSN: 0039-2944

\section{Notizia bibliografica digitale}

Filippo Fonio, «Gilles Banderier, Une lettre inédite d"Elie Vinet», Studi Francesi [Online], 145 (XLIX | I) |

2005, online dal 30 novembre 2015, consultato il 19 avril 2021. URL: http://journals.openedition.org/ studifrancesi/35902 ; DOI: https://doi.org/10.4000/studifrancesi.35902

\section{Questo documento è stato generato automaticamente il 19 avril 2021.}

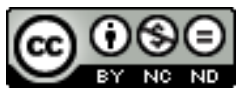

Studi Francesi è distribuita con Licenza Creative Commons Attribuzione - Non commerciale - Non opere derivate 4.0 Internazionale. 


\section{Gilles Banderier, Une lettre inédite d'Elie Vinet}

\section{Filippo Fonio}

\section{NOTIZIA}

GILLES BANDERIER, Une lettre inédite d'Elie Vinet, «Bibliothèque d'Humanisme et Renaissance», LXVI, 1 (2004), pp. 117-118.

1 La corrispondenza dell'erudito bordolese Elie Vinet è pubblicata nell'ambito dello studio di Louis Desgraves dedicato a questo personaggio, Elie Vinet humaniste de Bordeaux (1509-1587). Vie, bibliographie, correspondance, bibliothèque, Genève, Droz, 1977. Si tratta di quarantasei lettere che vanno dal 1543 al 1586, già edite in precedenza ma raccolte da Desgraves nella monografia in questione. Banderier ha reperito un'epistola inedita di Vinet, indirizzata al giurista e filologo Pierre Daniel, conservata nel ms. G.I. 26 dell'Universitätsbibliothek di Basilea. La lettera è datata al dicembre 1577 e riguarda uno scambio di libri fra i due umanisti. 